\title{
PENINGKATAN HASIL BELAJAR TEMATIK MODE PEMBELAJARAN CONTEXTUAL TEACHING AND LEARNING SISWA KELAS II SD NEGERI 163086 TEBING TINGGI
}

\author{
Helmina Siagian \\ Surel: hrmnsiagian@gmail.com
}

\begin{abstract}
This aim of this research is to improve learning result on thematic subject through contextual teaching and learning method. This classroom action research conducted by 2 cycles of the four phases: planning, implementation, observation, reflection. The subjects were students from class II, SDN 163086 Tebing Tinggi which amounted to 32 students. This study used a qualitative descriptive analysis technique. Based on data obtained from the measurement of the student learning outcomes on the cycle I of 78,12\% and cycle II amounted to $87,5 \%$ note there is an increase in student learning outcomes. This means learning the thematic using contextual teaching and learning method can improve learning outcomes in class II SDN 163086 Tebing Tinggi.
\end{abstract}

Key word : CTL, learning result, thematic

\begin{abstract}
ABSTRAK
Penelitian ini bertujuan untuk meningkatkan hasil belajar siswa mata pelajaran tematik melalui metode Contextual Teaching and Learning. Penelitian tindakan kelas ini dilaksanakan sebanyak 2 siklus. Subjek penelitian ini adalah siswa kelas II SDN 163086 Tebing Tinggi sebanyak 32 siswa. Penelitian ini menggunakan teknik analisis dekriptif kualitatif. Berdasarkan data yang diperoleh dari pengukuran ketuntasan belajar pada siklus I sebesar $78,12 \%$ dan siklus II sebesar $87,5 \%$ diketahui terdapat peningkatan hasil belajar siswa. Hal ini berarti pembelajaran tematik menggunakan metode contextual Teaching and Learning dapat meningkatkan hasil belajar siswa kelas II SDN 163086 Tebing Tinggi.
\end{abstract}

Kata Kunci : CTL, Hasil Belajar, Tematik

\section{PENDAHULUAN}

Salah satu upaya yang

dilakukan pemerintah dalam rangka meningkatkan mutu pendidikan nasional dan menghasilkan lulusan yang memiliki keunggulan kompetitif dan komparatif sesuai standar nasional. Maksudnya adalah perubahan orientasi pembelajaran yang berpusat pada guru (teacher centered) menjadi pembelajaran yang berpusat pada siswa (student centered). Dalam pembelajaran yang berpusat pada siswa, guru diharapkan dapat berperan sebagai fasilitator yang akan memfasilitasi siswa dalam belajar, dan siswa sendirilah yang harus aktif belajar dari berbagai sumber belajar.

Proses belajar anak tidak sekedar menghafal konsep-konsep dan fakta-fakta, tetapi merupakan kegiatan menghubungkan konsepkonsep untuk menghasilkan 
pemahaman yang lebih utuh. Pengetahuan ini tidak dapat ditransfer begitu saja dari seorang guru kepada anak.

Pembelajaran tematik merupakan pembelajaran yang memadukan materi beberapa mata pelajaran dalam satu tema (Henry, dkk, 2007:128). Pembelajaran tematik merupakan pembelajaran yang memadukan materi beberapa mata pelajaran dalam satu tema. Pembelajaran tematik dimaknai sebagai pembelajaran yang dirancang berdasarkan tema-tema tertentu. Pembelajaran tematik menyediakan keleluasaan dan kedalaman implementasi kurikulum, menawarkan kesempatan yang sangat banyak pada siswa untuk memunculkan dinamika dalam pendidikan. Unit yang tematik adalah epitome dari seluruh bahasa pembelajaran yang memfasilitasi siswa untuk secara produktif menjawab pertanyaan yang dimunculkan sendiri dan memuaskan rasa ingin tahu dengan penghayatan secara alamiah tentang dunia di sekitar mereka (Trianto, 2010: 147).

Pemilihan model pembelajaran tematik bagi siswa SD kelas rendah dikarenakan perkembangan peserta didik pada siswa SD kelas rendah pada umumnya tingkat perkembangannya masih melihat segala sesuatu sebagai satu keutuhan dan memahami hubungan antar konsep secara sederhana.

Kenyataan yang terjadi di SDN 163086 Tebing Tinggi pembelajaran terpadu bentuk tematik kurang dipahami sehingga dalam proses pembelajaran di kelas rendah (1 dan 2) di Sekolah Dasar masih terpisah berdasarkan mata pelajaran sehingga pembelajaran terpadu dengan bentuk tematik belum diterapkan sesuai dengan yang diharapkan. Hal tersebut bertolak belakang dengan tahapan perkembangan anak yang masih melihat segala sesuatu sebagai suatu keutuhan (holistic) sehingga pembelajaran yang menyajikan mata pelajaran terpisah akan menyebabkan kurang mendorong anak dalam pengembangan berpikir secara menyeluruh dan membuat kesulitan peserta didik.

Hasil penelitian di kelas II SD Negeri 163086 Tebing Tinggi ditemukan bahwa pembelajaran tematik telah dilaksanakan di kelas II, namun masih terdapat berbagai kekurangan, diantaranya dalam hal mengatasi mata pelajaran yang sulit untuk ditematikkan, pemilihan media pembelajaran serta dalam kegiatan evaluasi. Pembelajaran tematik serta latar belakang pendidikan guru yang masih rendah. Nilai rata-rata hasil belajar tematik siswa yaitu 65 . Hal ini menurut peneliti masih rendah. Maka dari itu perlu dilakukannya suatu model pembelajaran yang dapat meningkatkan pembelajaran siswa.

Untuk mengatasi permasalahan diatas, dapat menggunakan berbagai metode salah satunya adalah Contextual Teaching and Learning. CTL adalah suatu strategi pembelajaran yang 
menekankan kepada proses keterlibatan siswa secara penuh untuk dapat menemukan materi yang dipelajari dan menghubungkannya dengan situasi kehidupan nyata sehingga mendorong siswa untuk dapat menerapkannya dalam kehidupan mereka (Sanjaya, 2006:255).

\section{Contextual Teaching and}

Learning (CTL) merupakan konsep belajar yang membantu guru mengaitkan antara materi yang diajarkannya dengan situasi dunia nyata siswa dan mendorong siswa membuat hubungan antara pengetahuan yang dimilikinya dengan penerapannya dalam kehidupan mereka sebagai anggota dan masyarakat. CTL melibatkan tujuh komponen utama pembelajaran efektif, yakni: konstruktivisme (constructivism), bertanya (questioning), menemukan (inquiry), masyarakat belajar (learning community), pemodelan (modeling), refleksi (reflektion) dan penilaian sebenarnya (authentic assessment) (Nurhadi, 2003:5).

Menurut Mulyasa (2005:102), CTL merupakan konsep pembelajaran yang menekankan pada keterkaitan antara materi pembelajaran dengan dunia kehidupan peserta didik secara nyata, sehingga para peserta didik mampu menghubungkan dan menerapkan kompetensi hasil belajar dalan kehidupan sehari-hari. Pembelajaran CTL lebih menekankan pada proses belajar daripada sekedar hasil belajar. Apabila data yang dikumpulkan guru mengidentifikasi bahwa siswa mengalami kemacetan dalam belajar, maka guru segera bisa mengambil tindakan yang tepat agar siswa terbebas dari kemacetan belajar.

$$
\text { Hasil penelitian Rahtamaji }
$$
(2013), menyimpulkan bahwa pelaksanaan pembelajaran Ilmu Pengetahuan Sosial dengan menggunakan pendekatan Contextual Teaching Learning dapat meningkatkan hasil belajar siswa pada pembelajaran pada pembelajaran Ilmu Pengetahuan Sosial pada siswa kelas IV Sekolah Dasar Gunting Gilangharjo Pandak Bantul.

Berdasarkan permasalahan tersebut maka peneliti tertarik untuk meneliti metode ini karena siswa dapat terlibat secara aktif dalam kegiatan proses pembelajaran. Suasana belajar juga tercipta menyenangkan karena model ini dalam pelaksanaannya interaktif. Dengan menggunakan metode pembelajaran Contextual Teaching Learning, siswa diharapkan belajar mengalami bukan menghafal. Landasan filosofis CTL adalah konstruktivisme, yaitu filosofi belajar yang menekankan bahwa belajar tidak hanya sekedar menghafal, tetapi merekonstruksikan atau membangun pengetahuan dan ketrampilan baru lewat fakta-fakta atau proposisi yang merekaalami dalam kehidupannya (Muslich, 2009:41).

Berdasarkan uraian pada latar belakang masalah, maka dapat dirumuskan permasalahan sebagai berikut: "Apakah dengan menggunakan pembelajaran metode contextual teaching learning 
meningkatkan hasil belajar tematik siswa kelas II SD Negeri 163086 Tebing Tinggi Tahun pelajaran 2013/2014?"

Tujuan dari penelitian ini adalah untuk meningkatkan hasil belajar tematik siswa kelas II SD Negeri 163086 Tebing Tinggi tahun pembelajaran 2013/2014 melalui metode pembelajaran contextual teaching learning.

\section{METODE PENELITIAN}

Dalam penelitian ini, peneliti menggunakan metode deskriptif. Metode deskriptif adalah suatu metode penelitian yang ditujukan untuk menggambarkan fenomenafenomena yang ada, yang berlangsung pada saat ini, atau saat yang lampau. Adapun subjek penelitian adalah siswa kelas II SD Negeri 163086 Tebing Tinggi semester 1 tahun pelajaran 2013/ 2014 dan sumber data yang digunakan adalah siswa dan teman sejawat.

Pada Penelitian tindakan kelas data yang dikumpulkan dapat berbentuk kuantitatif maupun kualitatif. Penelitian tindakan kelas tidak menggunakan uji statistik, tetapi dengan deskriptif. Data kuantitatif yang berupa nilai dianalisis dengan menggunakan analisis deskriptif komparatif yaitu membandingkan nilai tes kondisi awal, nilai tes setelah siklus I, dan II yaitu nilai dari hasil ulangan harian siswa kelas II pada siklus I dan II. Komponen metode contextual teaching learning yang sangat data kualitatif yang berupa observasi kegiatan guru, dan sisa serta data kuantitatif yang berupa nilai hasil ulangan harian siswa kelas II. Prosedur penelitian tindakan kelas iniada tahap perencanaan tindakan, pelaksanaan tindakan, pengamatan dan evaluasi, dan refleksi.

Masing-masing siklus terdiri dari dua kali pertemuan yaitu sebagai berikut;

Perencanaan

Sebelum mengadakan penelitian peneliti menyusun rumusan masalah, tujuan dan membuat rencana tindakan, termasuk di dalamnya instrumen penelitian dan perangkat pembelajaran.

\section{Pelaksanaan}

Suatu tindakan ke dalam konteks proses belajar mengajar yang sebenarnya. Implementasi tindakan dimulai saat sebelum kegiatan dengan persiapan sebelum kegiatan dimulai, yaitu saat guru mengkondisikan siswa agar siap mengikuti pembelajaran.

\section{Siklus I}

Guru mengajar dengan menggunakan RPP yang telah disusun dan dipersiapkan sebelumnya. Sedangkan, peneliti dengan bantuan teman mengamati pelaksanaan tindakan dengan menggunakan lembar observasi yang telah dipersiapkan sebelumnya. Guru memberikan apersepsi, guru memberikan pengarahan tentang topik yang akan dipelajari, guru menerapkan pembelajaran tematik dengan menggunakan model contextual teaching and learning 
yang akan dipelajari. Selama kegiatan pembelajaran guru menerapkan langkah-langkah pembelajaran contextual teaching and learning yang mengacu pada skenario pembelajaran yang dibuat. Siswa belajar tematik dengan menggunakan model CTL dengan bimbingan guru.

\section{Siklus II}

Kegiatan awal yang dilakukan pada tahapan ini adalah guru memberikan apersepsi, guru memberikan pengarahan tentang topik yang akan dipelajari, guru menerapkan pembelajaran tematik dengan menggunakan model contextual teaching and learning yang akan dipelajari. Selama kegiatan pembelajaran guru menerapkan langkah-langkah pembelajaran contextual teaching and learning yang mengacu pada skenario pembelajaran yang dibuat. Siswa belajar tematik dengan menggunakan model CTL dengan bimbingan guru. Hal-hal yang dianggap kurang pada siklus I diperbaiki pada siklus II.

\section{Observasi/Pengamatan}

Pengamatan dilakukan peneliti sendiri dan dibantu oleh pengamat. Pelaksanaan observasi dilakukan pada saat proses pembelajaran berlangsung dengan berpedoman pada lembar observasi yang telah dibuat oleh peneliti.

\section{Refleksi}

Peneliti mengkaji, melihat dan mempertimbangkan hasil atau dampak dari tindakan yang dilakukan berdasarkan lembar pengamatan yang diisi oleh pengamat. Tahapan ini dilakukan secara berkesimbungan sehingga ditemukan hasil yang optimal.

Instrumen yang digunakan dalam penelitian ini adalah pedoman observasi, test hasil belajar, dan wawancara. Data aktivitas belajar dan kendala yang dihadapi selama proses pembelajaran dikumpulkan melalui observasi (lembar observasi terlampir). Hal-hal yang akan diobservasi adalah kegiatan lisan, kegiatan metrik, kegiatan emosional. Data hasil observasi, dan data hasil wawancara yang jenis datanya berupa pernyataan-pernyataan, dianalisis dengan menggunakan teknik analisis statistik deskriptif.

Metode pengumpulan data penelitian ini adalah tertulis dan observasi. Penelitian ini dikatakan berhasil apabila siswa telah memperoleh nilai ketuntasan secara klasikal minimal $85 \%$ dari jumlah siswa dengan rumus sebagai berikut:

Persentase Ketuntasan klasikal $=$ Jumlah siswa yang tuntas $\times 100 \%$ Jumlah siswa yang mengikuti tes

\section{HASIL DAN PEMBAHASAN}

Hasil data penelitian diuraikan berdasarkan siklus-siklus tindakan pembelajaran. Hasil data tersebut disesuaikan dengan masalah penelitian mencakup data perencanaan, dan proses pembelajaran. Data tentang perencanaan adalah persiapan guruan tertulis yang berupa satuan pelajaran. 
Hasil data ini didasarkan pada data yang telah dikumpulkan melalui pengamatan dan catatan lapangan ketika pembelajaran berlangsung.

Hasil penelitian tindakan kelas menunjukkan bahwa pengamatan yang dilakukan oleh mitra kolaborasi dan peneliti pada aktivitas guru dan siswa melalui penerapan metode contextual teaching and learning pada mata pelajaran tematik kelas II SD Negeri 163086 Tebing Tinggi dapat dilihat pada tabel sebagai berikut:

\begin{tabular}{|c|c|c|c|}
\hline \multirow{2}{*}{ Keterangan } & \multicolumn{3}{|c|}{ Peningkatan Hasil Belajar } \\
\cline { 2 - 4 } & $\begin{array}{c}\text { Pra } \\
\text { siklus }\end{array}$ & Siklus I & $\begin{array}{c}\text { Siklus } \\
\text { II }\end{array}$ \\
\hline $\begin{array}{c}\text { Nilai } \overline{\mathrm{X}} \\
\text { ulangan } \\
\text { harian }\end{array}$ & 65 & 72,36 & 73,30 \\
\hline $\begin{array}{c}\text { Jumlah } \\
\text { siswa }\end{array}$ & 21 & 25 & 28 \\
\hline $\begin{array}{c}\text { Persentase } \\
\text { Aktivitas } \\
\text { Siswa (\%) }\end{array}$ & 68 & 76,7 & 80,1 \\
\hline $\begin{array}{c}\text { Persen } \\
\text { Ketuntasan } \\
(\%)\end{array}$ & 65,62 & 78,12 & 87,5 \\
\hline
\end{tabular}

\section{Berdasarkan pengamatan} peneliti dari tindakan pra siklus, siklus I dan siklus II pada Tabel 1 terjadi peningkatan hasil belajar siswa. Hal ini dapat dilihat dengan peningkatan jumlah siswa dari 21 siswa yang tuntas belajar pada pra siklus menjadi 28 siswa yang tuntas belajar melalui model pembelajaran contextual learning teaching pada siswa kelas II SD Negeri 163086 Tebing Tinggi.

Nilai rata-rata kelas pembelajaran siklus I menunjukkan peningkatan bila dibanding dengan pra tindakan ke siklus I, yaitu dari 68,34 menjadi 72,36 . Nilai maksimal 83,3 dan nilai minimal 61,67. Sementara persentase ketuntasan belajar siswa yang telah mencapai KKM dari pra tindakan meningkat dari $65,62 \%$ menjadi $78,12 \%$ pada siklus I. Pada siklus II meningkat menjadi $87,5 \%$. Terjadi peningkatan 9,37\% dari siklus I. Pada pra tindakan dari 21 siswa dalam satu kelas, terdapat 11 siswa yang belum mencapai KKM, setelah mendapatkan metode pembelajaran contextual learning teaching, pada siklus II hanya 4 (empat) siswa yang belum memenuhi KKM atau $28(87,5 \%)$ siswa sudah tuntas belajar.

Hasil penelitian menunjukkan bahwa dengan proses pembelajaran dengan menggunakan model CTL terbukti dapat meningkatkan hasil belajar siswa pada mata pelajaran tematik. Materi tematik yang diajarkan kepada siswa adalah contoh nyata dalam kehidupan sehari-hari, sehingga pada proses pembelajaran semua materi dikaitkan dengan kehidupan sehari-hari dan sering dialami siswa.

Pada siklus I hasil belajar belum bisa dikatakan berhasil karena belum memenuhi kriteria ketuntasan. Hal tersebut dikarenakan pada saat pelaksanaan pembelajaran ada beberapa siswa yang pasif, karena siswa merasa tidak bisa dan berpangku tangan pada siswa lain dalam satu kelompok atau teman sebangkunya. Hasil refleksi yaitu berupa temuaan tingkat keefektifan desain pembelajaran dengan 
menggunakan Contextual Teaching Learning dengan penjelasan awal di kelas sebelum observasi dengan jelas dan pendampingan yang maksimal dalam kegiatan-kegiatan siswa dan daftar permasalahan yang muncul dilapangan dituangkan kembali kedalam rancangan tindakan berikutnya, selanjutnya tindakan refleksi terhadap rancangan yang telah disusun kembali sebelum digunakan.

Pada siklus II guru memberi arahan bahwa siswa yang akan presentasi dan yang akan diberi pertanyaan oleh guru akan dipilih secara acak. Bagi siswa yang tidak aktif dalam diskusi dan tidak serius dalam menguasai materi, tidak akan mampu presentasi dan menjawab pertanyaan ketika ditunjuk guru karena tidak menguasai materi. Bagi siswa yang berlaku seperti itu akanmendapat nilainya dan bagi yang aktif dan mampu membuat pertanyaan maupun menjawab pertanyaan akan ditambah nilainya. Sehingga menjadikan siswa berusaha untuk aktif dan berusaha menguasai materi karena merasa takut jika tidak bisa ketika ditunjuk. Akan tetapi ketika disuruh presentasi siswa tetap malu-malu untuk maju,takut jika salah. Guru memotivasi dengan memberi penghargaan nilai.

Penerapan menggunakan Contextual Teaching Learning dapat meningkatkan keefektifan pembelajaran dan hasil belajar tematik dengan baik. Pada siklus II ada 4 siswa kelas II yang tidak mengalami perubahan prestasi belajar atau tidak ada peningkatan prestasi, hal ini disebabkan karena:

a. Empat anak tersebut kurang serius, sehingga mengalami kesukaran dalam observasi, diskusi dan presentasi.

b. Empat siswa motivasi belajar rendah, acuh pada saat guru memberi contoh membaca maupun pada saat temannya tidak mau menyimak. Informasi guru kelas II, karena keseriusannya rendah.

Penerapan model contextual learning teaching yang digunakan pada siklus II ini lebih efektif dibandingkan pada siklus I hal ini terbukti dari peningkatan ketuntasan belajar siswa yang meningkat menjadi 28 siswa $(87,5 \%)$ dengan nilai ratarata 73,33 . Peningkatan ini terjadi karena guru mampu menciptakan situasi kondisi yang fleksibel (tidak terlalu kaku) dalam interaksi belajar, dan siswa belajar dari perasaan takut dan tekanan, melakukan kegiatan pembelajaran sesuai langkah-langkah yang direncanakan, sedemikian sehingga pada akhirnya siswa dapat menemukan sesuatu konsepnya sendiri yang diharapkan terbukti dapat meningkatkan hasil belajar dan sikap anak terhadap pelajaran tematik. Dengan melihat indikator yang telah ditetapkan sebelumnya, hasil yang diperoleh telah mencapai lebih dari batas minimal indikator keberhasilan sehingga penelitian tidak perlu dilanjutkan lagi untuk siklus berikutnya. Oleh karena itu dapat disimpulkan bahwa proses pembelajaran dengan penerapan 
model contextual learning teaching sangat sesuai dengan mata pelajaran tematik, maka Penelitian Tindakan Kelas (PTK) ini bisa dikatakan berhasil karena hasil peningkatan proses pembelajarannya optimal.

Model contextual learning teachingyang digunakan pada siklus II ini lebih efektif dibandingkan pada siklus I karena pembelajaran tematik yang berbasis kontekstual guru selalu mengaitkan materi pelajaran dengan kehidupan sehari-hari siswa, sehingga mata pelajaran tematik mudah dimengerti dan dipahami oleh siswa. Hal tersebut bertujuan agar materi mudah dipahami dan dimengerti oleh siswa apalagi objek kajian sosiologi adalah masyarakat sehingga siswa diharapkan aktif dalam proses belajar mengajar. Hal ini sejalan dengan pendapat Sanjaya (2008:225), CTL adalah suatu pendekatan pembelajaran yang menekankan kepada proses keterlibatan siswa secara penuh untuk dapat menemukan materi yang dipelajari dan menghubungkannya dengan situasi kehidupan nyata sehingga mendorong siswa untuk dapat menerapkannya dalam kehidupan mereka.

Hasil observasi menunjukkan bahwa pembelajaran dengan menggunakan model contextual learning teaching sudah berjalan semakin baik, peneliti sudah bisa mengarahkan siswa untuk bisa kerja secara kelompok dan melakukan kegiatan pembelajaran dengan model contextual learning teaching. Pengembangan proses pembelajaran kontekstual dapat dijadikan salah satu upaya untuk meningkatkan minat belajar siswa, agar siswa aktif terhadap mata pelajaran tematik. Dengan dikembangkannya proses pembelajaran kontekstual diharapkan dapat memberikan nuansa baru dalam pembelajaran tematik, sehingga adanya anggapan dari siswa bahwa pelajaran tematik merupakan pelajaran yang membosankan dan terkesan hanya teori saja lambat laun menjadi hilang.

Respon siswa dalam model pembelajaran contextual teaching and learning secara umum siswa merasa (setuju) dengan pembelajaran tematik model contextual teaching and learning. Kondisi ini berarti, bahwa sebagian besar siswa menikmati proses pembelajaran dengan model contextual teaching and learning. Siswa merasa lebih cepat mengerti dengan pendekatan pembelajaran yang digunakan. Maka dari itu model contextual teaching and learning terbukti meningkatkan hasil belajar siswa, terlihat dari hasil persentase ketuntasan belajar siswa yang mengalami peningkatan cukup drastis mulai dari pretest, siklus I hingga siklus II.

\section{KESIMPULAN}

Kesimpulan dari hasil penelitian di atas adalah dari hasil temuan penelitian tentang hasil belajar siswa mata pelajaran tematik dengan model contextual teaching and learning di kelas II SD Negeri 163086 Tebing Tinggi tahun pelajaran 2013/2014 berdampak positif dalam meningkatkan aktivitas 
dan hasil belajar siswa setiap siklusnya. Pada siklus II, langkahlangkah penerapan model pembelajaran contextual teaching and learning untuk meningkatkan keberhasilan siswa dilakukan dengan cara pemberian motivasi, pembagian kelompok kecil diskusi dan, serta memberikan kesempatan melakukan presentasi kelompok atas hasil praktikumnya di depan kelas. Hal tersebut dapat dilihat dari peningkatan persentase ketuntasan belajar siswa pada siklus I $(78,12 \%)$, siklus II $(87,5 \%)$ dan dinyatakan berhasil.

Dari hasil penelitian yang diperoleh beberapa saran agar proses belajar mengajar tematik lebih efektif dan memberikan hasil yang optimal bagi siswa yaitu:

a. Sebaiknya menyediakan sarana yang dapat mendukung kegiatan belajar mengajar dan pelatihan terhadap peneliti-peneliti kelas mengenai model contextual teaching and learning dan mengadakan pelatihan terhadap peneliti-peneliti kelas mengenai pendekatan-pendekatan pembelajaran khususnya pendekatan contextual teaching and learning dengan mengundang pakar yang ahli dibidangnya.

b. Disini guru dituntut untuk lebih kreatif dalam memvariasikan model pembelajaran, membimbing siswa untuk lebih aktif dalam memberikan umpan balik, membangkitkan minat belajar dan rasa ingin tahu, serta mengarahkan siswa untuk lebih aktif dalam pembelajaran penemuan dan berdiskusi.

c. Harus terlibat secara penuh baik secara fisik maupun mental dalam proses belajar mengajar, hal ini akan mempermudah tercapainya tujuan belajar.

\section{DAFTAR RUJUKAN}

Hernawan, Asep Henry, dkk. 2007. Belajar dan Pembelajaran $S D$. Bandung: UPI Press.

Mulyasa, E. 2005. Strategi Pembelajaran Berorientasi Standar Proses Pendidikan. Jakarta: Kencana.

Muslich, Mansur. 2009. KTSP Pembelajaran Berbasis Kompetensi dan Kontekstual. Jakarta: Bumi Aksara.

Sanjaya, Wina. 2006. Strategi Pembelajaran Berorientasi Standar Proses Pendidikan. Jakarta: Kencana Prenada Media Group.

Rahtamaji, A. 2013. Upaya Meningkatkan Hasil Belajar Ilmu Pengetahuan Sosial Melalui Pendekatan Contextual Teaching Learning Pada Siswa Kelas IV Sekolah Dasar Gunting Gilangharjo Pandak Bantul. Skripsi. Universitas Negeri Yogyakarta. 